\title{
THE IMPACT OF BANNING JUVENILE GUN POSSESSION
}

\author{
THOMAS B. MARVELL
}

Justec Research

\begin{abstract}
A 1994 federal law bans possession of handguns by persons under 18 years of age. Also in 1994, 11 states passed their own juvenile gun possession bans. Eighteen states had previously passed bans, 15 of them between 1975 and 1993. These laws were intended to reduce homicides, but arguments can be made that they have no effect on or that they even increase the homicide rate. This paper estimates the laws' impacts on various crime measures, primarily juvenile gun homicide victimizations and suicide, using a fixed-effects research design with state-level data for at least 19 years. The analysis compares impacts on gun versus nongun homicides and gun versus nongun suicides. Even with many different crime measures and regression specifications, there is scant evidence that the laws have the intended effect of reducing gun homicides.
\end{abstract}

\section{INTRODUCTION}

G UNS are the second leading cause of death in the United States among youths ages 10-24, and the firearm death rate for U.S. minors is 12 times the average for other industrialized countries. ${ }^{1}$ Gun murders of and by juveniles roughly doubled between 1985 and 1992, while the number of nongun murders remained stable. ${ }^{2}$ Consequently, governments have attempted to get guns out of the hands of juveniles. The federal government and probably all states have long prohibited gun sales to minors. ${ }^{3}$ Later laws, the subject of this study, go further and prohibit possession of guns by juveniles (aimed at, presumably, guns that were originally purchased by adults). States passed such laws with increasing frequency in the 1980s and early 1990s, and Title XI of the Federal Crime Control and Law Enforcement Act of 1994 made the ban effective nationwide on September 13, 1994.

Table 1 lists 34 state laws that ban juvenile gun possession, along with their effective dates (the laws only apply to violations on or after the

1 Susan DeFrancesco, Children and Guns, 29 Pace L. Rev. 275 (1999).

${ }^{2}$ James A. Fox \& Marianne W. Zawitz, Homicide Trends in the United States (2000).

${ }^{3}$ Jens Ludwig, Concealed-Gun-Carrying Laws and Violent Crime: Evidence from State Panel Data, 18 Int'l Rev. L. \& Econ. 239 (1998).

[Journal of Law and Economics, vol. XLIV (October 2001)]

(C) 2001 by The University of Chicago. All rights reserved. 0022-2186/2001/4402-0015\$01.50 
TABLE 1

Laws Banning Juvenile Handgun Possesson

\begin{tabular}{|c|c|c|c|}
\hline & Under Age of & Brief Citation & Effective Date \\
\hline Federal & 18 & $18-922(x)$ & September 13, 1994 \\
\hline Alaska $^{a}$ & 16 & 11.61 .220 & January 1,1980 \\
\hline Arizona $^{\mathrm{a}, \mathrm{b}}$ & 18 & $13-3111$ & July 18,1993 \\
\hline Arkansas $^{\mathrm{a}, \mathrm{b}}$ & 18 & $5-73-119$ & July 4,1989 \\
\hline California $^{a}$ & 18 & Penal 12101 & January 1, 1989 \\
\hline Colorado ${ }^{\mathrm{a}}$ & 18 & $18-12-108.5$ & September 13, 1993 \\
\hline Delaware & 18 & $11-1448$ & July 15,1994 \\
\hline Florida & 18 & 790.22 & January 1,1994 \\
\hline Georgia $^{\mathrm{b}}$ & 18 & $16-11-132$ & July 1,1994 \\
\hline Idaho $^{\text {b }}$ & 18 & $18-3302 \mathrm{~F}$ & July 1,1994 \\
\hline Illinois & 18 & $720-5 / 24-3$ & pre-1970 \\
\hline Indiana & 18 & $35-47-10-5$ & July 1,1994 \\
\hline Kansas $^{\mathrm{b}}$ & 18 & $21-4204 a$ & July 1,1994 \\
\hline Kentucky ${ }^{b}$ & 18 & 527.100 & July 15,1994 \\
\hline Michigan $^{\mathrm{a}}$ & 18 & $750.234 \mathrm{f}$ & March 28, 1991 \\
\hline Minnesota $^{a}$ & 18 & 624.713 & August 1,1975 \\
\hline Mississippi $^{\text {b }}$ & 18 & $97-37-14$ & July 1,1994 \\
\hline Nebraska $^{\mathrm{a}}$ & 18 & $28-1204$ & July 1,1978 \\
\hline $\mathrm{Nevada}^{\mathrm{b}, \mathrm{c}}$ & 18 & 202.300 & July 1, 1995 \\
\hline New Jersey ${ }^{a}$ & 18 & $2 C: 58-6.1$ & June 27,1980 \\
\hline New York ${ }^{\mathrm{a}}$ & 16 & 265.05 & September 1, 1974 \\
\hline North Carolina a,b & 18 & $14-269.7$ & September 1, 1993 \\
\hline North Dakota ${ }^{\mathrm{a}, \mathrm{b}}$ & 18 & $62.1-02-01$ & July 1,1985 \\
\hline Oklahoma a,b & 18 & $21-1273$ & June 7, 1993 \\
\hline Oregon $^{\mathrm{a}}$ & 18 & 166.250 & January 1,1990 \\
\hline Rhode Island ${ }^{\mathrm{b}}$ & 15 & $11-47-33$ & pre-1970 \\
\hline South Carolina ${ }^{\mathrm{b}}$ & 21 & $16-23-30$ & pre-1970 \\
\hline South Dakota ${ }^{\mathrm{b}}$ & 18 & $23-7-44$ & July 1, 1994 \\
\hline Tennessee & 18 & $39-17-1319$ & July 1,1994 \\
\hline $\mathrm{Utah}^{\mathrm{a}}$ & 18 & $76-10-509$ & October 21, 1993 \\
\hline Vermont $t^{b}$ & 16 & $13-4008$ & pre-1970 \\
\hline Virginia $^{a}$ & 18 & $18.2-308.7$ & July 1,1993 \\
\hline Washington ${ }^{\mathrm{b}}$ & 21 & 9.41 .040 & July 1,1994 \\
\hline West Virginia $^{\mathrm{a}, \mathrm{b}}$ & 18 & $61-7-8$ & July 9, 1989 \\
\hline Wisconsin & 18 & 948.60 & pre-1970 \\
\hline
\end{tabular}

Note. - Sixteen states do not have bans. Ten are Brady Act states (Alabama, Louisiana, Maine, Montana, New Hampshire, New Mexico, Ohio, Pennsylvania, Texas, and Wyoming), and six are non-Brady Act states (Connecticut, Hawaii, Iowa, Maryland, Massachusetts, and Missouri).

${ }^{a}$ States with laws effective 1974-93.

b Brady Act states. (Federal waiting periods and background checks apply in 1994 because these states did not have preexisting laws.)

${ }^{c}$ A pre-1970 Nevada law applied to persons under 14.

effective dates). This information was obtained through research into state statutory compilations and session laws, and it was checked against two other surveys. ${ }^{4}$

${ }^{4}$ Gwen A. Holden, et al., Compilation of State Firearm Codes that Affect Juveniles (1994); Bureau of Alcohol, Tobacco and Firearms, Firearms State Laws and Published Ordinances (20th ed. 1994) (hereafter referred to as ATF). 
The federal law, as well as the typical state law, makes it a misdemeanor for a person under 18 ( 21 in two states) to possess a handgun, with several exceptions, such as hunting or target shooting with the permission of a parent. Many state laws also ban possession of rifles and other deadly weapons by juveniles. As of 1994, five state bans applied only to persons younger than 15 or 16 (Table 1). These are not counted as juvenile gun ban laws for the purpose of this study because children that young seldom commit homicide. ${ }^{5}$ Among the states that did not enact juvenile gun possession bans, Massachusetts and New York have strict general gun possession laws, ${ }^{6}$ and lawmakers there might have believed that special laws for juveniles were unnecessary. The federal law also makes it illegal for a person to provide a minor with a handgun. Most states have similar laws, some enacted with the possession ban and some before the ban.

The issue addressed in this article is whether the juvenile gun possession bans have the effect of reducing gun homicides, especially of juveniles. The assumption behind the laws is that the bans reduce the number of juveniles who have guns and, thus, the number who use guns. ${ }^{7}$ The impact on crime might be limited because existing laws prohibited juveniles from purchasing guns, carrying concealed handguns, and possessing guns if they have been convicted of a felony. ${ }^{8}$ Thus, the question is whether crime rates are affected by a change from a situation where juveniles can possess guns, but cannot legally purchase or conceal them, to a situation where they can possess guns only with adult monitoring. Perhaps the major practical impact is creating disincentives to keeping guns at home. The laws might add an additional incentive for juveniles not to carry concealed weapons or purchase weapons since it adds a second charge when prosecuted, a charge that can be prosecuted in federal court.

An initial consideration is whether the bans increase the expected cost to juveniles for possessing guns, which largely determines whether the ban can have any effect. ${ }^{9}$ The costs include confiscation of the weapon, informal sanctions applied by such persons as relatives, juvenile officers, and prose-

\footnotetext{
${ }^{5}$ See Terry Allen \& Glen Buckner, A Graphical Approach to Analyzing Relationships between Offenders and Victims Using Supplementary Homicide Reports, 1 Homicide Stud. 129 (1997); and Michael D. Maltz, Visualizing Homicide: A Research Note, 14 J. Quantitative Criminology 397 (1998).

${ }^{6}$ ATF, supra note 4.

${ }^{7}$ There apparently is no statement that this is the actual intent of juvenile gun bans. The legislative history of the federal ban consists of justifications for federal action under the Commerce Clause of the U.S. Constitution; that is, guns and drug markets are interrelated and cross state lines. See Steven Rosenberg, Just Another Kid with a Gun? United States v. Michael R.: Reviewing the Youth Handgun Safety Act under the United States v. Lopez Commerce Clause Analysis, 28 Golden Gate Univ. L. Rev. 51 (1998).

${ }^{8}$ ATF, supra note 4.

9 See Philip J. Cook \& James A. Leitzel, "Perversity, Futility, Jeopardy": An Economic Analysis of the Attack on Gun Control, 59 Law \& Contemp. Probs. 91 (1996).
} 
cutors, and conviction and sentencing by courts. These costs are more likely to occur with greater efforts to uncover and report juveniles' gun possession. Information on all these topics is lacking, so it is impossible at this point to hypothesize whether the laws have much impact.

Assuming that possession actually entails a cost, there are many mechanisms by which the bans might affect the actual use of guns and, thus, crime rates. The most obvious is that juveniles who do not possess guns are less likely to carry guns and thus less likely to use them during crimes or altercations. If they do not possess guns, juveniles are less likely to retrieve them in the middle of a dispute or to use them later in retaliation. The bans can disrupt gun markets among juveniles because the law increases the costs of carrying gun inventories.

On the other hand, the gun bans might increase crime against young persons because criminals might consider them less risky targets. ${ }^{10}$ A criminal contemplating robbery or assault probably takes into consideration the likelihood that potential victims are armed and likely to defend themselves. If the potential victim appears to be under 18 years old, after a ban goes into effect, an aggressor might believe that armed resistance is less likely because of the juvenile gun possession ban. As discussed earlier, the possession bans do not make it any more illegal to carry a concealed handgun, but, again, the juvenile is less likely to have a handgun available if possession is less likely. The ban also can make aggression more likely because the aggressor is less concerned that the victim will retaliate by retrieving a gun.

An additional indicator of the impact of the juvenile gun possession bans is whether they reduce gun suicide by juveniles. There is a close relationship over time between the percentages of juvenile suicides and homicides by gun. ${ }^{11}$ One would expect that the choice of whether to use a gun in suicide depends largely on whether a gun is readily available. Although possession is only one of several factors suggesting availability, if the laws reduce possession, they should reduce gun suicides.

Preliminary indications of the likely impact can be seen in trends for gun homicide victimization for persons 15-19 years old, which is a group likely to be affected by the ban if it has an impact. Figure 1 plots the trends for the percentage of homicide victims who were killed by guns (since the number of nongun homicides changed little over time, the lines in Figure 1 also approximate trends in the number of gun homicides). This percentage rose from about 65 percent in the first half of the 1980s to 86 percent in 1992 , leveled off for 2 years, and then declined modestly. The leveling off occurred when more and more states were enacting juvenile gun possession

\footnotetext{
${ }^{10}$ For example, John R. Lott, Jr., \& David B. Mustard, Crime, Deterrence, and Right-toCarry Concealed Handguns, 26 J. Legal Stud. 1 (1997).

${ }^{11}$ Alfred Blumstein \& Daniel Cork, Linking Gun Availability to Youth Gun Violence, 59 Law \& Contemp. Probs. 5 (1996).
} 


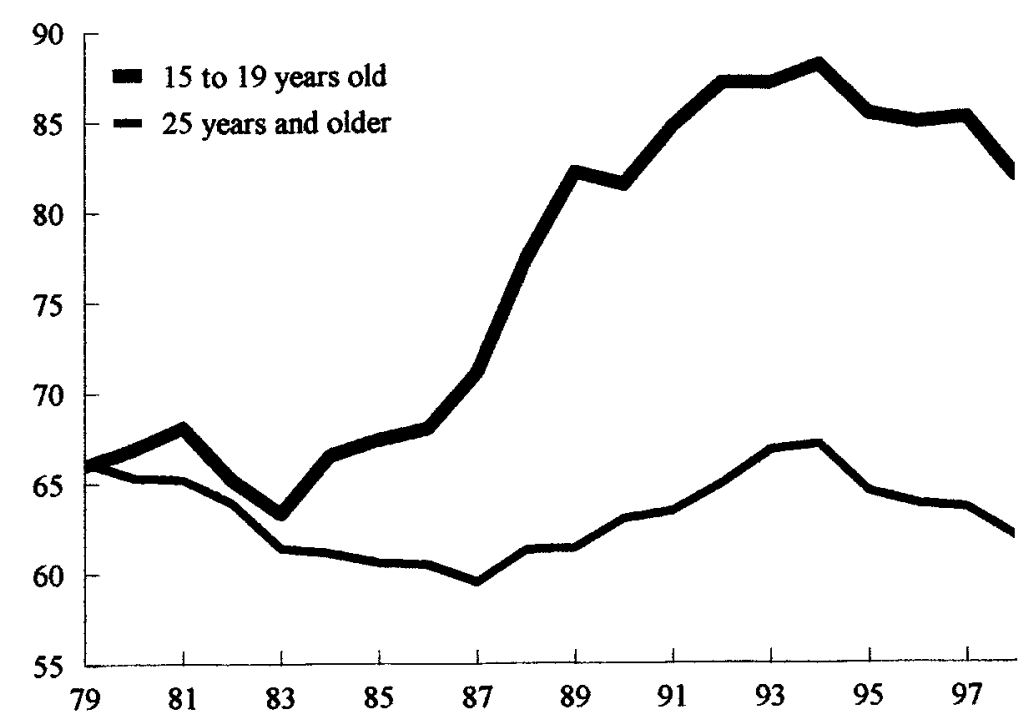

FIGURE 1.-Percent of homicides with guns

bans, and the decline occurred right after the substantial lawmaking activity in 1994, when most states first became covered by the ban (Table 1). At first glance, the trends suggest that the laws have the desired effect of reducing gun homicides. However, this impression disappears when one looks at trends in adult crimes; the post-1994 drop in percentage of homicides with guns occurred here as well. The initial impression from Figure 1 that the laws reduce gun homicide is probably only a reflection of general trends in homicides. ${ }^{12}$

The purpose of this paper is to explore this relationship with more elaborate data and analysis than are illustrated in Figure 1. The next section describes the methodology, which is a state-level multiple time-series regression that

\footnotetext{
${ }^{12}$ Commentators have given many reasons for the decline in murder and other crimes in the 1990s. I argue that it is due to the incapacitation impact of rising prison populations and the slackening of the crack era. Thomas B. Marvell \& Carlisle E. Moody, The Impact of Out-ofState Prison Population on State Homicide Rates: Displacement and Free-Rider Effects, 36 Criminology 513 (1998); Thomas B. Marvell \& Carlisle E. Moody, Female and Male Homicide Victimization Rates: Comparing Trends and Regressors, 37 Criminology 879 (1999). Other suggested causes include the legalization of abortion in the 1970s (John J. Donohue III \& Steven D. Levitt, The Impact of Legalized Abortion on Crime, 116 Q. J. Econ. 379 (2001)) and better police practices (Malcolm Gladwell, The Tipping Point: How Little Things Can Make a Big Difference (2000)).
} 
compares the impacts of the laws on different homicide categories. The third section describes the variables, and the fourth gives the results, which are that there is no evidence that the juvenile gun possession bans, taken as a whole, reduce gun homicides or total homicides.

\section{Methodology}

The multiple time-series regression has become a common tool to estimate the impact of legal changes, and the methods are continually improving. ${ }^{13}$ The regressions here encompass 45-50 states and 18-29 years, depending on the dependent variable, using the standard fixed-effects procedure. The regressions are weighted by population when the dependent variable is homicide and by lesser amounts (varying from population to the .3 power to population to the .7 power) for other crimes as determined by the BrueschPagan test. ${ }^{14}$ Weighting is necessary because crime rates vary over time more in small states, and weights are greater in homicide equations because homicides are less frequent events; so the discrepancy between variation in small and large states is especially large. The data start in 1970 because several control variables lack data for earlier years. The last year with available data is 1998 or 1999, depending on the series. The analysis, therefore, includes at least 4 full years of experience under each law. The main dependent variables are homicide victimizations for various age groups, and I use a sizeable number of other crime measures for robustness checks. The gun possession bans are represented by dummy variables.

The basic procedure is strengthened by comparing the estimated impacts of the laws on crimes that one would expect to be affected the most by the laws to the impacts on crimes less likely to be affected. The analysis, for example, compares the coefficients on the law dummies when gun homicides are the dependent variable with coefficients with nongun homicides. This helps control for missing variables that are not otherwise controlled for by the elaborate control mechanism possible with the multiple time-series design, as discussed below. The comparison is done with the STEST option in the SYSLIN procedure in SAS, ${ }^{15}$ which tests whether differences between co-

\footnotetext{
${ }^{13}$ For example, Lott \& Mustard, supra note 10; Thomas B. Marvell \& Carlisle E. Moody, Determinate Sentencing and Abolishing Parole: The Long-Term Impacts on Prisons and Crime, 34 Criminology 107 (1996).

${ }^{14}$ William H. Greene, Econometric Analysis 394-95 (2d ed. 1993).

${ }^{15}$ SAS Institute, SAS/ETS User's Guide, Version 6 (2d ed. 1993). Using the multiple timeseries procedure with dummy variables to evaluate the impact of laws or other impacts is the same as the difference-on-difference procedure (Jeffrey M. Wooldridge, Introductory Economics: A Modern Approach (2000)), but it has the benefit that one can set dummies at the effective date of each law that went into effect during the period when data are available, as opposed to setting a uniform date for all laws. Also, using an $F$-test to compare coefficients is an improvement on the difference-on-difference-on-difference procedure, whereby the impact of the law change on a crime type that is expected to be affected by the law is compared with the impact on a crime having no expected impact (for example, Ludwig, supra note 3 ). The
} 
efficients on an independent variable used in separate regressions are statistically significant.

\section{Dependent Variables ${ }^{16}$}

Most dependent variables are gun homicide victimization rates for various age groups and homicide offending rates by juveniles. When juveniles commit homicide, the victims are overwhelmingly persons of the same age or slightly older, ${ }^{17}$ so measures of gun homicide victimization are for persons in their late teens and early twenties. Alternate specifications use measures of juvenile homicide offending and general crime rate variables. All crimes are expressed as rates, divided by 100,000 persons in the age group in question. The numerous variables are best described in outline form.

\section{A. Victimization (Homicide and Suicide)}

1. The primary victimization data are from the Centers for Disease Control and Prevention Internet site, where state-level mortality data are available for 1979-98. In addition, earlier total homicide and gun homicide data were obtained from published mortality tables. ${ }^{18}$ The four types of data, and the years available, are the following:

a. Gun and nongun homicide victims, ages 15-19 (1979-98).

b. Gun and nongun homicide victims, ages 15-24 (1979-98).

c. Gun and nongun homicide victims of all ages (1968-98).

d. Gun and nongun suicide victims, ages 15-19 (1979-98).

2. Additional juvenile victimization data, compiled by James A. Fox in January 2001, were obtained from the Bureau of Justice Statistics (BJS) Internet site. Data are not used for five states for which observations are missing for more than 2 years (Florida, Iowa, Kansas, Maine, and Montana):

a. Homicide victims, ages 14-17 (1976-99).

b. Homicide victims, ages 14-24 (1976-99).

separate regressions mean that the two types of crime are allowed to have their own coefficients on the control variables, and again we need not set law dummies at the same year.

${ }^{16}$ The data set and basic programs used here are available from the author at marvell@cox.net or at http://www.mmarvell.com/justec.html.

${ }^{17}$ Allen \& Buckner, supra note 5; Maltz, supra note 5.

${ }^{18}$ Data are from National Center for Health Statistics, Vital Statistics of the United States 1978 (1982), and earlier versions. All the homicide data exclude legal homicides (executions and police killings). 


\section{B. Offending and Reported Crime}

Homicide arrests for the following two categories were also prepared by James A. Fox and placed on the BJS Internet site:

1. Homicide offending ages 14-17 (1976-99).

2. Homicide offending ages 14-24 (1976-99).

Finally, we use the seven Uniform Crime Report (UCR) categories (homicide, rape, robbery, assault, burglary, larceny, and auto theft) with data from 1968-99.

\section{Issues Pertaining to Homicide and Suicide Data}

Small states often have no juvenile homicides in any given year. Because this theoretically creates problems with regression analysis, I have dropped states from a given analysis if the dependent variable is zero for more than 2 years. The states that were dropped, which number up to 16 , are listed in the tables along with the regression results. In the parallel SYSLIN regressions, the state is dropped when data are missing for either dependent variable. For the remaining zero values (that is, one or two such zeros in a state), the number of homicides is set at .1 before logging (or for the Fox data sets, the homicide rate is set at .1). Coefficients on aggregate law variables change little when all states are included (because the regressions are weighted by population), but coefficients for individual state law dummies are erratic in states with many zero homicide years.

The juvenile homicide offending rates, because they are based on arrests, are probably overstated in relation to victimization rates and offending rates for older age groups because juveniles are less likely to escape arrest. ${ }^{19}$

We have no measure of gun homicides committed by juveniles, although that is the immediate target of the law, because data at the state level are very incomplete and erratic. As a practical matter, however, the measure of total juvenile homicide offending serves nearly the same purpose because the variation in homicide rates is largely due to variations in gun homicide rates. ${ }^{20}$ Also, for policy purposes, victimization is more important than offending because the overriding purpose of the laws is to reduce harm, and any impact on offending is simply the means to achieve that purpose.

\footnotetext{
${ }^{19}$ Howard N. Snyder, The Overrepresentation of Juvenile Crime Proportions in Robbery Clearance Statistics, 15 J. Quantitative Criminology 151 (1999); Thomas B. Marvell \& Carlisle E. Moody, Age Structure and Crime Rates: The Conflicting Evidence, 7 J. Quantitative Criminology 237 (1991).

${ }^{20}$ Fox \& Zawitz, supra note 2.
} 


\section{INDEPENDENT VARIABLES}

\section{A. Juvenile Gun Bans}

The key independent variables, of course, are those representing laws that ban juvenile gun possession, as listed in Table 1. After the year the law went into effect, the law variable is one. During that year, it is a decimal representing the portion of the year the law was in effect. The states are divided into three groups (Table 1): (1) 15 states that passed laws in 1975-93, (2) 11 states that passed laws in 1994, and (3) 21 states without laws by 1994 (the remaining three states had laws before 1970). ${ }^{21}$ Again, laws banning possession only for those under 15 or 16 are ignored. In the second group, the state laws went into effect only a few months before the federal law, so that dummy variables cannot separate their impact from that of the federal law. The main difference between the second and third groups is that the latter is affected only by the federal law, typically enforced only in the federal courts, whereas in the second group enforcement is possible in both state and federal courts. These 11 states received a double dose of law, although largely redundant (state authorities can enforce the federal law, and it is unlikely that federal prosecutors indict many juveniles for gun possession).

Homicides in the second and third groups of states, where dummy variables begin in 1994, are also subject to the changes made by other federal laws that year. The most important are waiting periods and background checks for firearm purchases, required under the Brady Act, beginning February 28, 1994. The act is applicable to the majority of states that did not already require waiting periods. ${ }^{22}$ These states are indicated in Table 1, and dummies representing the Brady Act for these states are included in later regressions. Also, the Crime Control and Law Enforcement Act of 1994 contains several major crimereduction programs such as truth in sentencing, enhanced penalties for drug offenses and using firearms in crimes, and funds for hiring new police and advancing community policing. These nationwide events are controlled for by entering year effects and by comparing gun and nongun crime regressions.

\section{B. Other Independent Variables}

Additional independent variables are those typically used in other statelevel studies of crime. ${ }^{23}$ These studies explain the theoretical importance of

\footnotetext{
${ }^{21}$ The fact that most law dummies are for the same year suggests that clustering effects might bias the $t$-ratios. To test for these, I used the ACOV option in SAS PROC REG, with the TEST statement for the law dummies. The resulting significance levels for the law dummies are very close to those for the original $t$-ratios.

${ }^{22}$ ATF, supra note 4.

${ }^{23}$ See Thomas B. Marvell \& Carlisle E. Moody, The Lethal Effects of Three-Strikes Laws, 30 J. Legal Stud. 89 (2001).
} 
the variables and describe the sources of data. Age structure variables are census data for the percent population of persons ages 15-17, 18-24, 25-29, and $30-34$, the ages with highest arrest rates. Economic variables are the unemployment rate, the number employed, real welfare payments, real personal income, and the poverty rate. Economic downturns might increase violent crime by increasing strain or might reduce it by reducing interaction among potential aggressors and victims. Prison population is the number of prisoners sentenced to more than 1 year, and it is the average of the current and prior year-end figures. All these variables are per capita and logged.

In addition, I make full use of the unique ability of the multiple timeseries design to control for missing variables-variables that are not known or that lack adequate data. State dummies control for such factors that cause crime rates to differ generally from one state to another. Year dummies control for missing variables that cause crime rates to rise or fall nationwide in a year. Separate linear trend variables for each state control for factors that cause trends in the state to differ from nationwide trends. Without them, coefficients on the law dummies are likely to be dominated by such trend differences, as opposed to any changes that took place at the time the law went into effect. Finally, lagged dependent variables reduce autocorrelation and further mitigate missing-variable bias. Two lags are entered when the dependent variables are UCR crimes and total gun and nongun victimization because data start before 1970. The remaining regressions have one lagged dependent variable and lose 1 year of data.

\section{Results}

The most important regressions are in Tables 2, 3, and 4, where dependent variables are homicide victimization rates for persons 15-19 years old, persons 15-24 years old, and all persons, respectively. For each table, there are two regressions, one with gun and one with nongun homicides. The coefficients for the early state laws are very small and not significant throughout except for the negative estimate for nongun total homicides (Table 4). On the one hand, the coefficients on the 1994 state law dummies are positive in the three gun homicide regressions, but only significant to the .10 level. On the other hand, the elasticities of up to .17 are fairly sizeable, and their decline as the age bracket expands is consistent with the suggestion that the 1994 state laws increase juvenile homicide. The 1994 state law dummy has no noticeable impact on nongun homicides. Finally, all coefficients on the "federal law only" dummies are negative, but significant to the .05 level only for gun homicides of all ages (Table 4), which is due solely to New York, a topic discussed later. As might be expected, in a separate analysis in which the 1994 state law variable and the federal law variable are combined into one variable, it is everywhere far from significant. The same result also occurs when the three law variables are combined into a single variable. 
TABLE 2

Homicide Victimizations of Persons Ages 15-19, Regressed on Juvenile Gun Ban Laws

\begin{tabular}{|c|c|c|c|c|}
\hline & \multicolumn{2}{|c|}{ Gun Homicide } & \multicolumn{2}{|c|}{ Nongun Homicide } \\
\hline & Coefficient & $t$ & Coefficient & $t$ \\
\hline Early state laws & .000 & .008 & -.135 & 1.175 \\
\hline 1994 state laws & .172 & 1.787 & -.010 & .068 \\
\hline Federal law only & -.045 & .582 & -.181 & 1.501 \\
\hline Ages $15-17$ & -.447 & .721 & .195 & .203 \\
\hline Ages $18-24$ & 2.181 & 3.473 & -.291 & .300 \\
\hline Ages 25-29 & .882 & 1.511 & -.775 & .862 \\
\hline Ages $30-34$ & 1.293 & 1.409 & -2.185 & 1.535 \\
\hline Unemployment rate & -.102 & .844 & .265 & 1.413 \\
\hline Employment & -1.222 & 1.068 & 1.816 & 1.022 \\
\hline Welfare & .193 & 1.010 & -.302 & 1.014 \\
\hline Military employment & .478 & 1.977 & .718 & 1.929 \\
\hline Real personal income & 1.672 & 1.711 & -.358 & .237 \\
\hline Poverty rate & -.039 & .374 & .246 & 1.499 \\
\hline Prison population & -.510 & 3.368 & -.192 & .819 \\
\hline Lag dependent variable & .174 & 4.409 & -.134 & 3.213 \\
\hline Degrees of freedom & 597 & & 597 & \\
\hline Adjusted $R^{2}$ & .90 & & .48 & \\
\hline \multicolumn{5}{|l|}{$F$-statistics: } \\
\hline For three law types & $1.59(.19)$ & & $1.21(.30)$ & \\
\hline \multicolumn{5}{|c|}{ For differences between equations: } \\
\hline Early state laws & \multicolumn{4}{|c|}{$.98(.32)$} \\
\hline 1994 state laws & \multicolumn{4}{|c|}{$1.05(.31)$} \\
\hline Federal law only & \multicolumn{4}{|c|}{$.90(.34)$} \\
\hline All three types & \multicolumn{4}{|c|}{$.74(.53)$} \\
\hline
\end{tabular}

Note. - These two regressions encompass 37 states over 19 years, 1980-98 (after losing a year because of the lagged dependent variable). Thirteen small states are not included because they had at least 3 years with zeros for one of the dependent variables (Alaska, Delaware, Hawaii, Idaho, Maine, Montana, Nebraska, New Hampshire, North Dakota, Rhode Island, South Dakota, Vermont, and Wyoming). Not shown are year dummies, state dummies, and individual state linear trend variables. The first three variables listed are dummies representing laws banning juvenile gun possession. Except for dummies and trends, the variables are per capita and logged. The first $F$-statistics are for the significance of the three law types taken as a group. The remaining $F$-statistics are for comparing coefficients on the individual law types, determining whether differences between the two equations and the net effect of the three are statistically significant. Numbers in parentheses are probabilities.

A key feature of these tables is the $F$-test to determine whether differences between each law dummy coefficients in gun and nongun homicide regressions are significant. The laws are designed to reduce gun use, and, if that were the only theory involved, one would not expect to see a reduction in nongun homicides. In fact, the laws might even increase nongun homicides because the reduced availability of guns might lead juveniles to substitute other means of killing. Thus, if the laws have their intended effects, one would expect the coefficients on the law dummies to be significantly lower in the gun homicide regressions. However, if the opposing theory-the one that holds that bans increase juvenile homicides because the victims are more vulnerable-dominates, both gun and nongun homicides should increase. The 
TABLE 3

Homicide Victimizations of Persons Ages 15-24, Regressed on Juvenile Gun Ban Laws

\begin{tabular}{|c|c|c|c|c|}
\hline & \multicolumn{2}{|c|}{ Gun Homicide } & \multicolumn{2}{|c|}{ Nongun Homicide } \\
\hline & Coefficient & $t$ & Coefficient & $t$ \\
\hline Early state laws & -.000 & .007 & .007 & .118 \\
\hline 1994 state laws & .129 & 1.757 & .124 & 1.450 \\
\hline Federal law only & -.079 & 1.324 & -.052 & .748 \\
\hline Ages $15-17$ & .195 & .419 & .140 & .259 \\
\hline Ages $18-24$ & 1.098 & 2.524 & -.136 & .271 \\
\hline Ages $25-29$ & 1.208 & 2.826 & -.101 & .207 \\
\hline Ages $30-34$ & .462 & .682 & -1.050 & 1.330 \\
\hline Unemployment rate & .018 & .202 & .135 & 1.295 \\
\hline Employment & -.336 & .388 & -.221 & .219 \\
\hline Welfare & .121 & .831 & .027 & .162 \\
\hline Military employment & .350 & 1.913 & .065 & .310 \\
\hline Real personal income & 1.366 & 1.901 & .811 & .970 \\
\hline Poverty rate & .007 & .089 & .097 & 1.047 \\
\hline Prison population & -.449 & 3.898 & -.200 & 1.497 \\
\hline Lag dependent variable & .211 & 6.005 & -.100 & 2.749 \\
\hline Degrees of freedom & 750 & & 750 & \\
\hline Adjusted $R^{2}$ & .91 & & .72 & \\
\hline \multicolumn{5}{|l|}{$F$-statistics: } \\
\hline For three law types & $2.44(.06)$ & & $1.29(.28)$ & \\
\hline \multicolumn{5}{|c|}{ For differences between equations: } \\
\hline Early state laws & & & $.01(.92)$ & \\
\hline 1994 state laws & & & $.00(.96)$ & \\
\hline Federal law only & & & - r $.09(.77)$ & \\
\hline All three types & & & .04 (.99) & \\
\hline
\end{tabular}

NotE. - See note to Table 2. The regressions encompass 46 states over 19 years, 1980-98. Four small states are excluded (New Hampshire, North Dakota, Vermont, and Wyoming).

increase might be greater for nongun homicides, because if the attacker no longer fears the victim has a gun, he or she is less likely to rely on the quickest and most lethal means of attack.

In practice, both hypotheses receive little support. Nowhere in Tables 2-4 is there evidence that the laws cause gun homicides to decline more than nongun homicides. The hypothesis that the laws increase homicides receives only very slight support: the difference for early state laws in Table 4 is significant to the .10 level. With the large number of comparisons and $F$ tests, however, one such result is to be expected by chance. Finally, an important result is that coefficients on the three law variables as a group are not significantly different between the gun and nongun variables (last rows in Tables 2-4).

By aggregating the laws into three groups in Tables 2-4, I am assuming that the coefficients on the dummies are the same for each law in a group. Similar assumptions are common in time-series cross-sectional analyses of legal changes, but they are unrealistic. One would expect that impacts vary 
TABLE 4

Homicide Victims, All Ages, Regressed on Juvenile Gun Ban Laws

\begin{tabular}{|c|c|c|c|c|}
\hline & \multicolumn{2}{|c|}{ Gun Homicide } & \multicolumn{2}{|c|}{ Nongun Homicide } \\
\hline & Coefficient & $t$ & Coefficient & $t$ \\
\hline Early state laws & -.002 & .080 & -.063 & 2.529 \\
\hline 1994 state laws & .060 & 1.659 & .014 & .400 \\
\hline Federal law only & -.084 & 2.786 & -.048 & 1.670 \\
\hline Ages $15-17$ & .158 & .829 & .036 & .196 \\
\hline Ages 18-24 & .186 & 1.029 & .170 & .966 \\
\hline Ages $25-29$ & .365 & 2.130 & .282 & 1.719 \\
\hline Ages 30-34 & -.167 & .784 & .249 & 1.197 \\
\hline Unemployment rate & -.069 & 1.794 & .068 & 1.829 \\
\hline Employment & -.151 & .464 & 1.114 & 3.465 \\
\hline Welfare & -.149 & 3.093 & -.175 & 3.744 \\
\hline Military employment & .213 & 3.107 & .260 & 3.897 \\
\hline Real personal income & .408 & 1.774 & -.372 & 1.650 \\
\hline Poverty rate & -.002 & .057 & .076 & 1.838 \\
\hline Prison population & -.172 & 4.456 & -.147 & 3.882 \\
\hline Lag dependent variable & .349 & 12.774 & .106 & 3.919 \\
\hline Second lag dependent variable & .173 & 6.212 & .050 & 1.885 \\
\hline Degrees of freedom & 1,307 & & 1,307 & \\
\hline Adjusted $R^{2}$ & .95 & & .90 & \\
\hline \multicolumn{5}{|l|}{$F$-statistics: } \\
\hline For three law types & $5.55(.001)$ & & $3.25(.02)$ & \\
\hline \multicolumn{5}{|c|}{ For differences between equations: } \\
\hline Early state laws & \multicolumn{4}{|c|}{$2.94(.09)$} \\
\hline 1994 state laws & \multicolumn{4}{|c|}{$.83(.36)$} \\
\hline Federal law only & \multicolumn{4}{|c|}{$.72(.39)$} \\
\hline All three types & \multicolumn{4}{|c|}{$1.90(.13)$} \\
\hline
\end{tabular}

Note. - See note to Table 2. The regressions encompass all 50 states for 29 years, 1970-98.

between states because of differences in the precise terms of the laws, enforcement efforts, other contemporaneous changes in criminal law and operations, and preexisting conditions. To address this problem, each law is given a separate dummy variable, which is zero except in the postlaw period in the particular state. Dummies were not entered for three states that had laws before 1970. Because we only have data for juvenile homicides beginning in 1979, regressions with these variables do not include dummies for three early laws. Also, as indicated in Tables 2-4, several small states were deleted because they had more than 2 years with no homicides.

As expected, the coefficients vary greatly (Table 5). The coefficients for New York stand out; they are negative, large, and highly significant because of the extreme decline in homicide rates there since the early 1990s. Most coefficients are positive, however, and a few are large. One cannot attribute these, or any other individual coefficient in Table 5, specifically to the juvenile gun possession bans because the coefficients might be affected by other contemporaneous changes that are not captured by control variables, although the multiple time-series design permits numerous controls. Assuming that 
TABLE 5

Gun Homicide Victimization Regressed on Individual State Law Dummies

\begin{tabular}{|c|c|c|c|c|c|c|}
\hline & \multicolumn{2}{|c|}{ AgES $15-19$} & \multicolumn{2}{|c|}{ AgES $15-24$} & \multicolumn{2}{|c|}{ All Ages } \\
\hline & Coefficient & $t$ & Coefficient & $t$ & Coefficient & $t$ \\
\hline \multicolumn{7}{|l|}{$\begin{array}{l}\text { States passing laws } \\
\text { in 1975-93: }\end{array}$} \\
\hline Arizona & .284 & .942 & .299 & 1.316 & .302 & 2.922 \\
\hline Arkansas & .546 & 1.275 & .203 & .630 & .110 & .805 \\
\hline California & .163 & 1.315 & .135 & 1.451 & .081 & 1.883 \\
\hline Colorado & -.367 & 1.189 & -.065 & .280 & .168 & 1.500 \\
\hline Michigan & -1.002 & 4.504 & -.553 & 3.319 & -.188 & 2.668 \\
\hline Minnesota & $\ldots$ & $\ldots$ & $\ldots$ & $\ldots$ & -.293 & 2.965 \\
\hline Nebraska & $\ldots$ & $\ldots$ & $\ldots$ & & -.225 & 1.411 \\
\hline New Jersey & $\ldots$ & $\ldots$ & $\ldots$ & $\ldots$ & -.025 & .308 \\
\hline North Carolina & .036 & .145 & .044 & .237 & .101 & 1.274 \\
\hline North Dakota & & & & & -.331 & 1.201 \\
\hline Oklahoma & -.245 & .737 & -.062 & .251 & .079 & .706 \\
\hline Oregon & .752 & 2.129 & -.388 & 1.455 & -.250 & 2.066 \\
\hline Utah & .360 & .838 & .498 & 1.540 & .342 & 2.245 \\
\hline Virginia & -.105 & .424 & .082 & .442 & .162 & 1.972 \\
\hline West Virginia & -.064 & .133 & -.271 & .740 & -.120 & .773 \\
\hline \multicolumn{7}{|l|}{$\begin{array}{l}\text { States passing laws } \\
\text { in 1994: }\end{array}$} \\
\hline Delaware & & & .537 & 1.070 & .295 & 1.227 \\
\hline Florida & -.112 & .690 & .047 & .383 & -.011 & .202 \\
\hline Georgia & -.202 & .823 & -.118 & .639 & .108 & 1.303 \\
\hline Idaho & & & .617 & 1.490 & .421 & 2.165 \\
\hline Indiana & .752 & 3.065 & .743 & 3.986 & .261 & 2.994 \\
\hline Kansas & .212 & .596 & .347 & 1.290 & .229 & 1.795 \\
\hline Kentucky & 1.076 & 3.586 & .448 & 1.995 & .248 & 2.365 \\
\hline Mississippi & -.149 & .414 & -.069 & .258 & .021 & .169 \\
\hline South Dakota & & & -.271 & .544 & -.176 & .752 \\
\hline Tennessee & .462 & 1.757 & .217 & 1.096 & .181 & 1.976 \\
\hline Washington & -.282 & 1.020 & -.150 & .723 & .081 & .861 \\
\hline \multicolumn{7}{|c|}{$\begin{array}{l}\text { Federal law (states } \\
\text { without laws by } \\
\text { 1994): }\end{array}$} \\
\hline Alabama & -.083 & .297 & .033 & .158 & .116 & 1.150 \\
\hline Alaska & & & .675 & 1.230 & .476 & 1.758 \\
\hline Connecticut & -.263 & .827 & -.107 & .446 & -.107 & .928 \\
\hline Hawaii & $\ldots$ & & .121 & .306 & .379 & 1.987 \\
\hline Iowa & .630 & 1.855 & .505 & 1.968 & .254 & 2.112 \\
\hline Louisiana & -.282 & 1.010 & -.199 & .945 & .052 & .533 \\
\hline Maine & $\ldots$ & & .433 & 1.166 & .015 & .088 \\
\hline Maryland & .290 & 1.076 & .053 & .264 & .148 & 1.576 \\
\hline Massachusetts & .077 & .300 & -.130 & .671 & -.091 & 1.021 \\
\hline Missouri & -.438 & 1.753 & -.249 & 1.324 & -.022 & .244 \\
\hline Montana & .104 & .171 & .360 & .780 & .134 & .612 \\
\hline Nevada & -.219 & .460 & .078 & .219 & .280 & 1.613 \\
\hline New Hampshire & $\ldots$ & & & & -.197 & 1.047 \\
\hline New Mexico & .089 & .204 & .236 & .713 & .342 & 2.151 \\
\hline New York & -.468 & 3.078 & -.506 & 4.387 & -.551 & 9.415 \\
\hline Ohio & .119 & .677 & .047 & .356 & .005 & .088 \\
\hline Pennsylvania & .537 & 2.936 & .395 & 2.870 & .276 & 4.250 \\
\hline Rhode Island & .193 & .343 & .172 & .405 & -.274 & 1.357 \\
\hline
\end{tabular}




\begin{tabular}{|c|c|c|c|c|c|c|}
\hline Texas & -.379 & 2.127 & -.254 & 1.900 & -.184 & 3.109 \\
\hline Vermont & $\ldots$ & $\ldots$ & $\ldots$ & $\ldots$ & -.252 & .956 \\
\hline Wyoming & $\ldots$ & & & & -.112 & .378 \\
\hline \multicolumn{7}{|c|}{ Means (with $t$-ratios): } \\
\hline All laws & .073 & .818 & .096 & 1.938 & .048 & 1.447 \\
\hline Early states & .032 & .224 & -.007 & .071 & -.006 & .099 \\
\hline 1994 states & .224 & 1.174 & .214 & 1.921 & .151 & 2.515 \\
\hline Federal only & -.005 & .067 & .088 & 1.280 & .033 & .591 \\
\hline
\end{tabular}

NotE. - See note to Table 2. These three regressions are the essentially the same as the regressions in the "Gun Homicide" columns in Tables 2-4, except that there are separate law dummies for each state. The Minnesota, Nebraska, and New Jersey laws are not included in the first two regressions because the laws went into effect before or during 1980, when the data in the regressions start. The remaining blank spaces occur because states are deleted if they have 3 or more years with no murders. The $t$-ratio for the means is based on the standard error of the means, which is a conservative estimate.

the other changes are largely random, the overall impact of each law type can be estimated by taking the means of the coefficients. ${ }^{24}$ As seen at the end of Table 5, these estimates are generally consistent with those in Tables $2-4$, although the evidence is a little stronger that the 1994 state laws are associated with more gun homicides. ${ }^{25}$

Table 6 gives the results of the analysis of suicides of persons ages 15-19 years, presenting only the results concerning the law variables. In regressions similar to those in Table 2, the law dummies are never significant and there is no evidence of a difference between gun and nongun suicide. It is likely, however, that any impact of the laws is dampened in Table 6 because the suicide measure includes persons 18 and 19 years old, who are not covered by the gun possession ban, and unlike with the gun homicide measures, one would expect an exact correspondence between age and impact of the law.

Next, in Tables 7-9, the basic homicide regressions are replicated with seven additional homicide measures, again using dummies for the three types of laws. Only the law coefficients are shown. The results are consistent with the gun homicide regressions in Tables 2-4; the 1994 state laws have positive coefficients, while the federal law has negative coefficients, significant in two regressions. Coefficients on the federal law are greatly affected by New

\footnotetext{
${ }^{24}$ There is no uniformly accepted way to calculate the standard error of means of coefficients. The procedure used in Table 6 is that recommended in M. Hashem Persaran \& Ron Smith, Estimating Long-Run Relationships from Dynamic Heterogenous Panels, 68 J. Econometrics 79 (1995). Another procedure is to calculate the standard deviation of the mean by dividing the mean standard deviation by the square root of the number of law dummies involved (see Badi H. Baltagi \& James M. Griffin, Pooled Estimators vs. Their Heterogeneous Counterparts in the Context of Dynamic Demand for Gasoline, 77 J. Econometrics 303 (1997)), which usually produces larger $t$-ratios. Baltagi \& Griffin, supra, and Pesaran \& Smith, supra, address coefficient heterogeneity by conducting separate regressions for each unit. That is not feasible here because the time series are too short and, more importantly, because separate regressions are likely to be misspecified because they lack year effects.

${ }^{25}$ One reason for the slight differences between the means in Table 5 and the law coefficients in Tables 2-4 is that the latter are based on regressions weighted by population, whereas the means in Table 5 treat each coefficient equally and thus emphasize smaller states. Thus, excluding New York has little impact on the mean for the federal law only states in Table 5.
} 
TABLE 6

Suicide Rates Regressed on Juvenile Gun Ban Laws (Ages 15-19), 1980-98

\begin{tabular}{|c|c|c|c|c|}
\hline & \multicolumn{2}{|c|}{ FIREARM } & \multicolumn{2}{|c|}{ NONFIREARM } \\
\hline & Coefficient & $t$ & Coefficient & $t$ \\
\hline Early state laws & -.009 & .155 & .127 & 1.346 \\
\hline 1994 state laws & .005 & .063 & .022 & .187 \\
\hline Federal law & -.060 & .940 & .078 & .800 \\
\hline Number of states & 46 & & 46 & \\
\hline Degrees of freedom & 750 & & 750 & \\
\hline Adjusted $R^{2}$ & .78 & & .36 & \\
\hline \multicolumn{5}{|l|}{$F$-statistics: } \\
\hline Three law types & $.35(.79)$ & & $.77(.51)$ & \\
\hline \multicolumn{5}{|c|}{ For difference between equations: } \\
\hline Early state laws & \multicolumn{4}{|c|}{$1.58(.21)$} \\
\hline 1994 state laws & \multicolumn{4}{|c|}{$.01(.92)$} \\
\hline Federal law only & \multicolumn{4}{|c|}{$1.40(.24)$} \\
\hline All three types & \multicolumn{4}{|c|}{$.97(.41)$} \\
\hline
\end{tabular}

NOTE. - This table gives coefficients on the three law variables from regressions that are the same as in Table 2 except for the dependent variables.

York, and when it is dropped from the analysis, there is no evidence that the federal law reduces homicide.

Table 9 also analyzes UCR crimes other than homicides. If the laws actually reduce gun possession, they might reduce these crimes because some juveniles might be reluctant to commit them without the protection of firearms. If the laws embolden criminals to commit crimes because they believe that victims who appear to be juveniles are less likely to be armed, then one would expect these other crimes to increase after the bans. The increases would probably be greater for violent crimes, where the offender comes into contact with the victim. All these possible impacts, however, are likely to be muted because the bans do not apply to adults, who comprise the majority of victims and offenders, and there are no useable data disaggregated by age. In any event, there is no sign that the bans affect nonhomicides (Table 9). In particular, the $F$-statistics for the three law types are far from significant.

The regressions discussed thus far were also estimated with a wide variety of variable specifications. Results change little when law variables are lagged 1 year or converted into distributed lags (a linear trend until the fourth lag). The same is true when the regression is conducted in differences, when the continuous variables are not per capita, and when they are not logged. Coefficients on the 1994 state law variable are usually a little larger and more likely to be significant when the law variable is lagged, but they are less likely to be significant when variables are differenced or not logged.

As stated earlier, interpretation of the 1994 laws is uncertain because many other nationwide changes were made that year. The regression design mitigates this problem by entering year dummies and state trends and by com- 
TABLE 7

Homicide Victimization Rates Regressed on Juvenile Gun Ban Laws

\begin{tabular}{|c|c|c|c|c|c|c|c|c|}
\hline & \multicolumn{4}{|c|}{$1980-98$} & \multicolumn{4}{|c|}{$1977-99$} \\
\hline & \multicolumn{2}{|c|}{ Ages 15-19 } & \multicolumn{2}{|c|}{ Ages $15-24$} & \multicolumn{2}{|c|}{ Ages $14-17$} & \multicolumn{2}{|c|}{ Ages 14-24 } \\
\hline & Coefficient & $t$ & Coefficient & $t$ & Coefficient & $t$ & Coefficient & $t$ \\
\hline Early state laws & -.021 & .332 & .024 & .547 & .000 & .005 & .035 & .879 \\
\hline 1994 state laws & .160 & 1.910 & .132 & 2.285 & .157 & 1.339 & .092 & 1.320 \\
\hline Federal law & -.063 & .932 & -.064 & 1.383 & -.166 & 2.261 & -.125 & 2.817 \\
\hline$F$ for three types & $2.21(.09)$ & & $3.59(.01)$ & & $3.00(.03)$ & & $4.51(.004)$ & \\
\hline Number of states & 44 & & 49 & & 34 & & 42 & \\
\hline Degrees of freedom & 716 & & 801 & & 672 & & 838 & \\
\hline Adjusted $R^{2}$ & .87 & & .92 & & .80 & & .89 & \\
\hline
\end{tabular}

Note. - This table gives coefficients on the three law variables from regressions that are the same as in Table 2 except for the dependent variables.

paring coefficients in gun and nongun homicides. Still, the best estimates are probably for the pre-1994 laws, which were passed before the spate of federal law activity. There is virtually no evidence that the pre-1994 laws have an impact.

Another way to control for at least some of the other changes occurring around 1994 is to add dummy variables for specific laws. I added three categories to the regressions in Tables 2-4. The first is background checks for handgun purchases, which under the Brady Act were first applied after February 1994 in 33 states that did not already have background checks (indicated in Table 1). ${ }^{26}$ The second is that 24 states have three-strikes laws (usually enhanced penalties for third violent felonies). ${ }^{27}$ The third is that 25 states have shall-issue laws (which facilitate concealed handgun permits). ${ }^{28}$ These additions had very little impact on the results reported above. ${ }^{29}$

${ }^{26}$ Jens Ludwig \& Philip J. Cook, Homicide and Suicide Rates Associated with Implementation of the Brady Handgun Violence Prevention Act, 284 JAMA 585 (2000).

${ }^{27}$ See Marvell \& Moody, supra note 23.

${ }^{28}$ See Lott \& Mustard, supra note 10. The dates for these laws are as follows: Alaska, August 30, 1994; Arizona, July 17, 1994; Arkansas, July 8, 1995; Florida, October 1, 1987; Georgia, August 25, 1989; Idaho, July 1, 1990; Kentucky, October 1, 1996; Louisiana, April 19, 1996; Maine, August 7, 1980; Mississippi, July 1, 1990; Montana, October 1, 1991; Nevada, October 1, 1995; New Hampshire, August 1, 1994; North Carolina, December 1, 1995; Oklahoma, September 1, 1995; Oregon, January 1, 1990; Pennsylvania, June 18, 1989, and October 19, 1995; South Carolina, August 23, 1996; Tennessee, July 1, 1994; Texas, August 28, 1995; Utah, May 1, 1995; Virginia, July 1, 1983, and July 1, 1995; West Virginia, July 1, 1988; Wyoming, October 1, 1994.

${ }^{29}$ Analysis of the results for these three law variables is outside the scope of this paper. A rough summary is that the shall-issue laws have little discernable impact except for reducing rape. The three-strikes laws are strongly associated with increases in almost all measures of homicide (the major exceptions are nongun homicides of persons ages 15-19 and 15-24). The likely reasons for this result are discussed in Marvell \& Moody, supra note 23. The Brady Act is also strongly associated with more homicides (except victimizations of persons ages 15-19 and 15-24), as well as with robbery, burglary, and auto thefts. A possible reason is that criminals believe that citizens are more vulnerable. However, this finding suffers from the 
TABLE 8

Homicide Arrest Rates Regressed on Juvenile Gun Ban Laws, 1977-99

\begin{tabular}{|c|c|c|c|c|}
\hline & \multicolumn{2}{|c|}{ AgEs $14-17$} & \multicolumn{2}{|c|}{ AgES 14-24 } \\
\hline & Coefficient & $t$ & Coefficient & $t$ \\
\hline Early state laws & .054 & .796 & .080 & 1.843 \\
\hline 1994 state laws & .218 & 1.784 & .159 & 2.103 \\
\hline Federal law & -.095 & 1.254 & -.070 & 1.454 \\
\hline$F$ for three types & $2.31(.08)$ & & $4.03(.01)$ & \\
\hline Number of states & 35 & & 44 & \\
\hline Degrees of freedom & 693 & & 880 & \\
\hline Adjusted $R^{2}$ & .83 & & .86 & \\
\hline
\end{tabular}

NOTE. - This table gives coefficients on the three law variables from regressions that are the same as in Table 2 except for the dependent variables.

The next analysis is another comparison of coefficients, with young person and adult victimizations as dependent variables. If the juvenile handgun bans act to increase homicides because criminals have less cause to fear that victims are armed, then the impact should fall only on persons whom the attacker believes to be juveniles (it is possible, however, that offenders might refrain from attacking adults if there are juveniles present whom the offender believes might be armed). Although the bans apply to persons under 18, the attacker often does not know the victim's age and might believe older persons are similarly without gun protection. In any event, I use victimizations of persons ages $14-17,15-19$, and 15-24. Likewise, it is difficult to determine which age group is not affected, and the variables used are persons older than 19 and persons older than 24 . These various combinations lead to five comparisons, and there is no indication of a difference between the age groups for any of the three law types.

It is possible that the apparent lack of crime-reduction impact of the law is due to simultaneity - that is, state legislatures pass juvenile bans in response to rising juvenile homicide, such that this positive relationship counteracts a negative impact of the laws. This possibility is suggested by Figure 1 and Table 1. Most laws in the "early state law" category were enacted in the late 1980s and early 1990s, just when juvenile gun homicide was increasing. Although these crimes peaked in about 1992, the 1994 federal and state laws might be in response to the trends in the prior decade. This issue is addressed in two ways. First, any such simultaneity would be mitigated (but not eliminated) by lagging the law dummy variables, because the legislatures are not

fact that the categorization of states as Brady Act states and non-Brady Act states by Ludwig \& Cook, supra note 26, has little to do with the extent of gun control exercised before and after the Brady Act. Several Brady Act states (subjected to the law) already had strong gun control laws, while the federal government classified several states as non-Brady Act states on the basis of laws passed just before the Brady Act went into effect. In all, because of this problem and because of the positive coefficients on the Brady Act variable, I question the results in Ludwig \& Cook, supra note 26. 
TABLE 9

Uniform Crime Report Crime Rates Regressed on Juvenile Gun Ban Laws (50 States, 1,353 Degrees of Freedom), 1970-99

\begin{tabular}{|c|c|c|c|c|c|c|c|c|c|c|c|c|c|c|}
\hline & \multicolumn{2}{|c|}{ HомісіDE } & \multicolumn{2}{|l|}{ RAPE } & \multicolumn{2}{|c|}{ RoBbeRY } & \multicolumn{2}{|c|}{ Assault } & \multicolumn{2}{|c|}{ BURGLARY } & \multicolumn{2}{|c|}{ LARCENY } & \multicolumn{2}{|c|}{ Auto Theft } \\
\hline & Coefficient & $t$ & Coefficient & $t$ & Coefficient & $t$ & Coefficient & $t$ & Coefficient & $t$ & Coefficient & $t$ & Coefficient & $t$ \\
\hline Early state laws & .003 & .161 & -.010 & .702 & -.002 & .113 & -.000 & .011 & .001 & .171 & .010 & 1.260 & -.001 & .093 \\
\hline 1994 state laws & .051 & 1.741 & -.026 & 1.326 & .019 & .790 & -.024 & 1.186 & -.008 & .604 & .009 & .856 & .007 & .333 \\
\hline Federal law & -.076 & 3.180 & -.013 & .827 & .007 & .361 & -.027 & 1.563 & -.015 & 1.281 & .001 & .119 & -.017 & .944 \\
\hline$F$ for three types & $\begin{array}{l}6.89 \\
(.001)\end{array}$ & & $\begin{array}{l}.67 \\
(.57)\end{array}$ & & $\begin{array}{c}.24 \\
(.87)\end{array}$ & & $\begin{array}{c}.99 \\
(.40)\end{array}$ & & $\begin{array}{l}.62 \\
(.60)\end{array}$ & & $\begin{array}{l}.71 \\
(.55)\end{array}$ & & $\begin{array}{l}.51 \\
(.67)\end{array}$ & \\
\hline Adjusted $R^{2}$ & .95 & & .97 & & .99 & & .98 & & .98 & & .98 & & .98 & \\
\hline
\end{tabular}

NotE. - This table gives coefficients on the three law variables from regressions that are the same as in Table 2 except for the dependent variables. Two dependentvariable lags are used. 
influenced by crime rates in the next year. As discussed earlier, lagging the dummy has little impact on the results.

Another way to explore possible simultaneity is the Granger test. ${ }^{30}$ Using a probit procedure, with the variables listed in Table 2 plus the state effects, the law dummies are regressed on crime lagged 2 years, as well as the law dummies lagged 2 years. If rising crime caused the laws to be enacted, the coefficients on the crime variables would be significant and positive. ${ }^{31}$ The analysis showed that there is no evidence of this for any of the three law categories and for any of the numerous crime measures. Most coefficients on lagged crime (the regressions use lags of 1 and 2 years) are negative, and none is positive and significant.

\section{CONCLUSION}

Juvenile handgun bans have little or no impact on a wide variety of crime measures. This finding renders the analysis more difficult than if an impact were found. Most published evaluations of laws do find an impact one way or another, and they typically only present a regression with significant results, with perhaps a few supporting analyses. Such a procedure, however, is not valid to show the absence of an impact because still other specifications might uncover an apparent impact. Also, the lack of significant results does not mean absence of impact, just that it is less likely. One can never claim to have covered all possibilities, but this paper attempts to mitigate these by using numerous crime measures as well as several configurations of the law variables and of the continuous variables. The multiple time-series design using coefficient comparisons, moreover, provides far more controls than other procedures.

One can posit theories that the juvenile gun bans either increase or decrease homicides. If the bans reduce juvenile gun access, they would probably reduce the use of guns by juveniles in crimes. If the bans lead others to believe that juveniles are more vulnerable targets, the result is likely to be more crime, especially violent crimes involving juveniles. The finding that the laws have little or no impact could mean that both types of theories are without merit or that they cancel each other out. The former appears more likely. It is not likely that theories cancel each other in a similar way for so many different

\footnotetext{
${ }^{30}$ Clive W. J. Granger, Investigating Causal Relations by Econometric Models and CrossSpectral Methods, 37 Econometrica 424 (1969).

${ }^{31}$ The rationale for the Granger test is that there is no simultaneity between the dependent variable and lagged independent variable, so long as the lagged dependent variable is entered to control for possible serial correlation between the lagged independent variable and dependent variable through the lagged dependent variable. It is possible for the Granger test to miss causation if it occurs only in the current year, since the current year independent variable is not entered (because the causal direction in the current year is undetermined). This is very unlikely here because the legislature in one year is unlikely to react only to crime in that year and not consider crime in the prior year.
} 
crime measures, and the lack of impact on juvenile suicide rates suggests that the laws do not reduce gun access.

The results are almost uniform with respect to the pre-1994 state laws banning juvenile gun possession: they have no discernible crime-reduction impact, and there is only very slight evidence of an increase, mainly with respect to total gun homicides (Table 5). The results for the 1994 law variables are more uncertain because the results might be influenced by substantial federal efforts commenced that year to regulate guns and reduce crime generally. Where the 1994 laws seem to have an impact, the suggestion is almost always that crime increases; thus, there is no evidence that these bans had their intended effect. There is some slight support for the theory that the bans increase homicides because juveniles appear more vulnerable. With aggregate law variables, this effect appears mainly for state 1994 laws and it is usually counterbalanced by negative results for the federal 1994 law. The strongest indication occurs when the law variable is disaggregated, but these results are affected by large positive coefficients in a few small states. Finally, there is no discernable difference between the impact of the laws on murders by juveniles and those by adults; if the laws encouraged crime, the impact would only apply to the former.

\section{BIBLIOGRAPHY}

Allen, Terry, and Buckner, Glen. "A Graphical Approach to Analyzing Relationships between Offenders and Victims Using Supplementary Homicide Reports." Homicide Studies 1 (1997): 129-40.

Baltagi, Badi H., and Griffin, James M. "Pooled Estimators vs. Their Heterogeneous Counterparts in the Context of Dynamic Demand for Gasoline." Journal of Econometrics 77 (1997): 303-27.

Blumstein, Alfred, and Cork, Daniel. "Linking Gun Availability to Youth Gun Violence." Law and Contemporary Problems 59 (1996): 5-24.

Bureau of Alcohol, Tobacco and Firearms. Firearms State Laws and Published Ordinances, 20th ed. Washington, D.C.: Department of the Treasury, 1994.

Cook, Philip J., and Leitzel, James A. “'Perversity, Futility, Jeopardy': An Economic Analysis of the Attack on Gun Control." Law and Contemporary Problems 59 (1996): 1-118.

DeFrancesco, Susan. "Children and Guns." Pace Law Review 29 (1999): 275-92.

Donohue, John J., III, and Levitt, Steven D. "Legalized Abortion and Crime." Quarterly Journal of Economics 116 (2001): 379-420.

Fox, James Alan, and Zawitz, Marianne W. Homicide Trends in the United States. Washington, D.C.: U.S. Department of Justice, 2000.

Gladwell, Malcolm. The Tipping Point: How Little Things Can Make a Big Difference. Boston: Little, Brown \& Company, 2000. 
Granger, Clive W. J. "Investigating Causal Relations by Econometric Models and Cross-Spectral Methods." Econometrica 37 (1969): 424-38.

Greene, William H. Econometric Analysis. 2d ed. New York: Macmillan Publishing Co., 1993.

Holden, Gwen A., et al. Compilation of State Firearm Codes that Affect Juveniles. Washington, D.C.: National Criminal Justice Association, 1994.

Lott, John R., Jr., and Mustard, David B. "Crime, Deterrence, and Right-toCarry Concealed Handguns.” Journal of Legal Studies 26 (1997): 1-68.

Ludwig, Jens. "Concealed-Gun-Carrying Laws and Violent Crime: Evidence from State Panel Data." International Review of Law and Economics 18 (1998): 239-54.

Ludwig, Jens, and Cook, Philip J. "Homicide and Suicide Rates Associated with Implementation of the Brady Handgun Violence Prevention Act." JAMA 284 (2000): 585-91.

Maltz, Michael D. "Visualizing Homicide: A Research Note." Journal of Quantitative Criminology 14 (1998): 397-410.

Marvell, Thomas B., and Moody, Carlisle E. "Age Structure and Crime Rates: The Conflicting Evidence.” Journal of Quantitative Criminology 7 (1991): 237-73.

Marvell, Thomas B., and Moody, Carlisle E. "Determinate Sentencing and Abolishing Parole: The Long-Term Impacts on Prisons and Crime." Criminology 34 (1996): 107-28.

Marvell, Thomas B., and Moody, Carlisle E. "The Impact of Out-of-State Prison Population on State Homicide Rates: Displacement and Free-Rider Effects." Criminology 36 (1998): 513-36.

Marvell, Thomas B., and Moody, Carlisle E. "Female and Male Homicide Victimization Rates: Comparing Trends and Regressors." Criminology 37 (1999): 879-902.

Marvell, Thomas B., and Moody, Carlisle E. "The Lethal Effects of ThreeStrikes Laws.” Journal of Legal Studies 30 (2001): 89-106.

National Center for Health Statistics. Vital Statistics of the United States 1978. Washington, D.C.: Government Printing Office, 1982.

Pesaran, M. Hashem, and Smith, Ron. "Estimating Long-Run Relationships from Dynamic Heterogenous Panels." Journal of Econometrics 68 (1995): 79-113.

Rosenberg, Steven. "Just Another Kid with a Gun? United States v. Michael R.: Reviewing the Youth Handgun Safety Act under the United States $v$. Lopez Commerce Clause Analysis." Golden Gate University Law Review 28 (1998): 51-88.

SAS Institute. SAS/ETS User's Guide. Version 6, 2d ed. Cary, N.C.: SAS Institute, 1993.

Snyder, Howard N. "The Overrepresentation of Juvenile Crime Proportions 
in Robbery Clearance Statistics." Journal of Quantitative Criminology 15 (1999): 151-62.

Wooldridge, Jeffrey M. Introductory Economics: A Modern Approach. Cincinnati: South-Western College Publishing, 2000. 